\title{
QUANTIFICATION OF PHYSICAL LOSSES PRODUCTS IN A PLANT OF FEED
}

Paulo Carteri Coradi ${ }^{1}$, Adílio Flauzino de Lacerda Filho² José Benício Paes Chaves $^{3}$, Evandro de Castro Melo ${ }^{4}$

\begin{abstract}
The aim of the study was to evaluate the quantity, costs and contaminations of the physical losses of products (corn, meals, flours, feeds, and micro ingredients) caused by the maintenance system utilized in equipment of the different stages of a feed production mill. The experiment was conducted in a feed industry with production capacity of 1,000 ton day ${ }^{-1}$. Firstly, an assessment of the maintenance system used in the feed mill was performed, after the products losses were quantified in the external and internal sectors of the milling steps. Two methods were utilized for loss quantification: per sector and per equipment of the feed industry. Samples of the products were collected in different points of the area evaluated for counting of fungi and salmonella colonies, insects and mites. The results showed that a large number of maintenances were not performed within the programmed period, up to $70 \%$. In addition, the equipment maintenance system utilized in the feed milling significantly influenced product losses, reaching $120 \mathrm{~kg}$ and costs of US\$ 38 per hour worked. The microbiological analysis presented a high contamination index by fungi and salmonellas sp. $\left(7,4 \times 10^{4} \mathrm{CFU} \mathrm{g}^{-1}\right)$ in corn grain.
\end{abstract}

Keywords: control, industry, ingredients, processing, quality.

\section{RESUMO}

\section{QUANTIFICAÇÃO DAS PERDAS FÍSICAS DE PRODUTOS EM UMA FÁBRICA DE RAÇÃo}

O objetivo do estudo foi avaliar o quantitativo, os custos e as contaminações das perdas físicas de produtos (milho, farelos, farinhas, rações, e micro ingredientes), causada pelo sistema de manutenção utilizado nos equipamentos das diferentes fases de produção de uma fábrica de ração. O experimento foi realizado em uma indústria de rações com capacidade de produção de 1000 ton dia $^{-1}$. Em primeiro lugar, foi feito um levantamento do sistema de manutenção utilizado na fábrica de ração, após as perdas de produtos foram quantificados nos diferentes setores externos e internos da fábrica de ração. Dois métodos foram utilizados para quantificação das perdas: por setor e por equipamentos da indústria de rações. Amostras de produtos foram recolhidas em diferentes pontos da área avaliada para contagem de fungos e salmonelas, insetos e ácaros. Os resultados mostraram elevado número de manutenções não realizado dentro do período programado, chegando a 70\%. Além disso, o sistema de manutenção de equipamentos utilizados na indústria de ração influenciou significativamente as perdas de produtos, chegando até $120 \mathrm{~kg}$ e custos de US\$38 por hora de trabalho. A análise microbiológica apresentou um alto índice de contaminação de fungos e salmonelas sp. (7.4 x $10^{4} \mathrm{UFC} \mathrm{g}^{-1}$ ) em grãos de milho.

Palavras-chave: controle, indústria, ingredientes, processamento, qualidade.

Recebido para publicação em 02/04/2013. Aprovado em 11/12/2014.

1 - Engenheiro Agrícola, Professor Adjunto da UFMS/CPCS-Chapadão do Sul-MS, paulo.coradi@ufms.br

2 - Engenheiro Agrônomo, Professor Titular da UFV/DEA-Viçosa-MG, alacerda@ufv.br

3 - Engenheiro Agrônomo, Professor Titular da UFV/DTA-Viçosa-MG, jbchaves@ufv.br

4 - Engenheiro Agrícola, Professor Associado da UFV/DEA-Viçosa-MG, evandro@ufv.br 


\section{INTRODUCTION}

Despite the significant quantities of grain produced in Brazil due to technology advances in the agricultural sector, improvements must be made in regards to quality and control. Product losses during harvest and post-harvest periods are observed year after year, however, real numbers for losses are not yet known and few suitable methods for control have been obtained. Some studies and estimates have been performed, but results still show significant variation of $16 \% \pm 4 \%$ for practically all crops (JARDINE, 2002; WU, 2004; CORADI et al., 2011). Today, these indexes are outdated and must be revised. The Brazilian Post-Harvest Association admits a shortage of data with respect to this subject, indicating that the most recent work is the report produced by the Technical Commission for Reduction of Agricultural Losses, of the Brazilian Department of Agriculture, Storage and Agrarian Reform (JARDINE, 2002). The same institution affirmed that during storage, losses generally occur due to inadequate structures or storage networks, as well as poorly qualified workers which operate dryers, fumigation chambers, aerators and other equipment for reception, transportation and conservation of products in the storage units. In grain storage facilities and feed mills, losses are observed as product leaks from equipment. Product leaks are not tabulated in the majority of grain storage units since the products are often collected and returned to the production process, running the risk of physical, chemical and biological contamination (BENNET; KLICH, 2003; PETTERSSON, 2004; KRSKA et al., 2005; SCHATZMAYR et al., 2006) of the rest of the lot and compromising the final product quality (BRERA et al., 2004).

Among the contamination types, both fungi contamination and mycotoxins production are some of the most important in storage facilities and feed mills (WHITAKER, 2003; WU, 2004). Fusarium, Aspergillus, and Penicillium are the most abundant molds that produce these toxins and contaminate human foods and animal feeds through fungal growth both prior to and during harvest, or during storage (BHATNAGAR et al., 2004; FRAGA et al., 2007). In production units, such as feed mills, gains in productivity, quality and profits are extended to control systems, including the preventive maintenance of production equipment and machinery. The application of an effective preventive maintenance program, without downtime and unexpected interventions of equipment during production, favors income, uptime, product quality, and fewer product losses. To implement a preventive maintenance program it is necessary to observe the production equipment, defining the maintenance execution schedule, as well as the organization's warehouse, spare parts and records regarding previously performed maintenance.

The aim of this study was to evaluate quantity, costs and contaminations of physical product losses caused by maintenance of equipment in the different production stages of a feed mill.

\section{MATERIALS AND METHODS}

This study was performed in a commercial poultry feed mill unit located in the State of Minas Gerais, Brazil, with a daily production capacity of 1,000 tons of animal feed. The feed mill unit included a parking area for grain trucks and automobiles, and also a weighing system of raw materials with an automatic scale system. Unloading of bulk products (corn kernel and soybean meal) is performed in separated hoppers, while for bagged raw materials a manual system is utilized for the individual units. The grain pre-cleaning system consists of an air machine and sieves with 600 ton $\mathrm{h}^{-1}$ capacity, in which light impurities are removed. In this system, impurities and damaged grains are separated in the sieves based on size and shape, considering the quality standards adopted by the industry. Grain drying is performed in a continuous flow dryer with a nominal capacity of 60 ton $\mathrm{h}^{-1}$. The product is transported within the mill unit by bucket elevators, belt conveyers and screw augers. Storage units consist of eight metallic silos, four with 1,200 ton capacity each, and the other four capable of storing 2,100 tons each. Corn kernel storage is composed of eight more silos with 200 ton capacity each. Theses silos are used at the peak of the harvest season, in the final drying of products (dry aeration) to bring water content from about $16.5 \%$ to $12.0 \%$. Soybean meal is stored in two cement silos with 350 ton capacity each.

Another six metallic silos with capacities of 100 tons are also used to store soybean meal. Micro ingredients, including methionine, lysine, lime, salt, sodium bicarbonate, premixes, vitamins, rice and wheat mills are stored in an internal area of the mill unit. Weighing of micro ingredients is done manually and they are mixed in a pre-mixer. The ingredient mixing system for feed production is composed of a pre-mixer, mixers and a hopper bin, with 4,000 $\mathrm{kg}$ capacity. The system is operated and controlled automatically by a computer. Weighing and addition of ingredients is performed in a hopper for receiving of mills, doser and doser bins, oil (fat) tanks and a

\section{REVENG}

$$
\text { 105-118p. }
$$


weighing scale. The control system is automatic and computerized for addition of the following products: soybean, wheat, visceral, meat and feather meals; corn germ, and visceral oils according to the specific feed formulation. After weighing and adding ingredients, the products are ground together. The grinding system is composed of hammer millers, each with a rated power of $128.0 \mathrm{~kW}$. Pelletization is conducted by using pelletizers with 25 ton capacity each, operating at a temperature and pressure of $73{ }^{\circ} \mathrm{C}$ and $750 \mathrm{kgf} \mathrm{m}^{-2}$. After formation, pellets are cooled to remove excess water and heat. Feed loading is in bulk, utilizing hopper bins and storage silos, with 60 ton capacity each. Discharge is done directly into bulk feed trucks.

Evaluation was realized by collecting data referring to the maintenance system used in the feed mill. Standard maintenance was established as a function of the feed mill itself. All the mechanical components of the bucket elevator, auger and belt conveyer, silos, dryer, pre-cleaning, mixer, doser, pelleting, and grinder were evaluated. The maintenance system was analyzed considering the preventive maintenance performed during the programmed period, preventative maintenance not performed during the programmed period, anticipated preventative maintenance and maintenance not performed.

The following products were quantified: soybean corn, visceral, bone, meat and feather meals; sorghum, integral soybeans, oils of viscera, feeds and other micro ingredients including: methionine, lysine, lime, salt, sodium bicarbonate, premixes and vitamins. All products encountered on the mill floor or in environments unsuitable for the product were considered as physical losses. These losses were quantified both inside (industrialization process) and outside (raw materials process) of the feed mill (Figure 1 and Table 1). The product sampling points were selected before initiating the study and they were maintained until the end of the experiment. Two different quantification methods were utilized: per sector of the mill and per equipment. In quantification of product losses

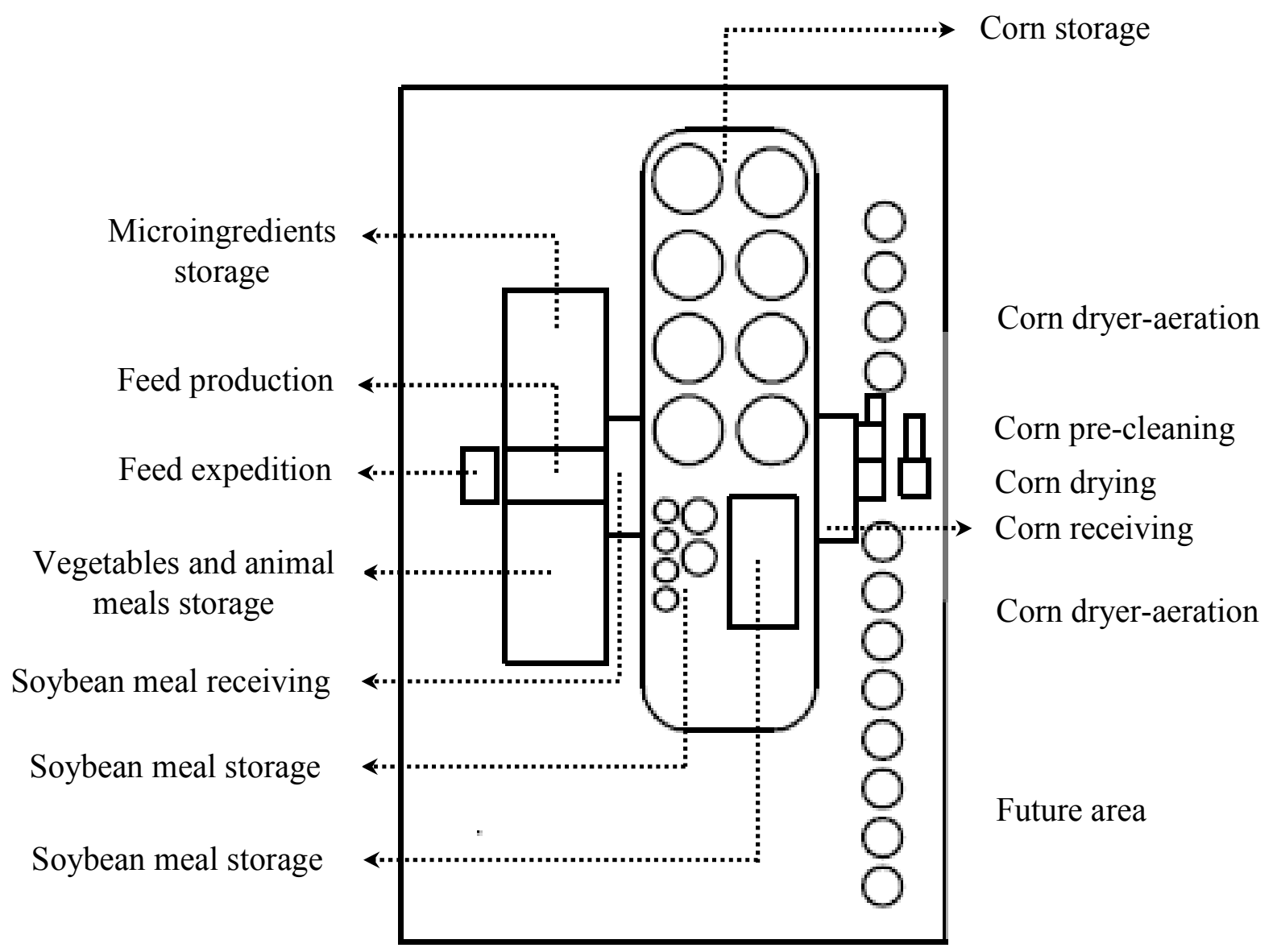

Figure 1. Partial feed milling plant and points of product loss sampling. 
Table 1. Dates and schedules of sampling of the products on the floor of the feed mill

\begin{tabular}{|c|c|c|c|c|}
\hline Months & Weeks & Dates & Times (h) & Ingredients \\
\hline \multirow{12}{*}{ May } & \multirow[t]{3}{*}{1} & $05 / 05$ & 7:00 / 10:00 / 13:00 / 16:00 / 19:00 & Corn grains \\
\hline & & $05 / 07$ & 8:00 / 11:00 / 14:00 / 17:00 / 20:00 & Soybean / animal meals \\
\hline & & 05/09 & $6: 00 / \quad 9: 00 / 12: 00 / 15: 00 / 18: 00$ & Feed / microingredients \\
\hline & \multirow[t]{3}{*}{2} & $05 / 12$ & 7:00 / 10:00 / 13:00 / 16:00 / 19:00 & Feed / microingredients \\
\hline & & $05 / 14$ & $8: 00 / 11: 00 / 14: 00 / 17: 00 / 20: 00$ & Corn grains \\
\hline & & $05 / 16$ & $6: 00 /$ 9:00 / 12:00 / 15:00 / 18:00 & Soybean / animal meals \\
\hline & \multirow[t]{3}{*}{3} & $05 / 19$ & 7:00 / 10:00 / 13:00 / 16:00 / 19:00 & Soybean / animal meals \\
\hline & & $05 / 21$ & $8: 00 / 11: 00 / 14: 00 / 17: 00 / 20: 00$ & Feed / microingredients \\
\hline & & $05 / 23$ & $6: 00 / \quad 9: 00 / 12: 00 / 15: 00 / 18: 00$ & Corn grains \\
\hline & \multirow[t]{3}{*}{4} & $05 / 26$ & 7:00 / 10:00 / 13:00 / 16:00 / 19:00 & Corn grains \\
\hline & & $05 / 28$ & $8: 00 / 11: 00 / 14: 00 / 17: 00 / 20: 00$ & Soybean / animal meals \\
\hline & & $05 / 30$ & $6: 00 / \quad 9: 00 / 12: 00 / 15: 00 / 18: 00$ & Feed / microingredients \\
\hline \multirow{12}{*}{ June } & \multirow[t]{3}{*}{1} & $06 / 02$ & 7:00 / 10:00 / 13:00 / 16:00 / 19:00 & Feed / microingredients \\
\hline & & $06 / 04$ & $8: 00 / 11: 00 / 14: 00 / 17: 00 / 20: 00$ & Corn grains \\
\hline & & $06 / 06$ & $6: 00 / \quad 9: 00 / 12: 00 / 15: 00 / 18: 00$ & Soybean / animal meals \\
\hline & \multirow[t]{3}{*}{2} & $06 / 09$ & 7:00 / 10:00 / 13:00 / 16:00 / 19:00 & Soybean / animal meals \\
\hline & & $06 / 11$ & $8: 00 / 11: 00 / 14: 00 / 17: 00 / 20: 00$ & Feed / microingredients \\
\hline & & $06 / 13$ & $6: 00 / \quad 9: 00 / 12: 00 / 15: 00 / 18: 00$ & Corn grains \\
\hline & \multirow[t]{3}{*}{3} & $06 / 16$ & 7:00 / 10:00 / 13:00 / 16:00 / 19:00 & Corn grains \\
\hline & & $06 / 18$ & $8: 00 / 11: 00 / 14: 00 / 17: 00 / 20: 00$ & Soybean / animal meals \\
\hline & & $06 / 20$ & $6: 00 / \quad 9: 00 / 12: 00 / 15: 00 / 18: 00$ & Feed / microingredients \\
\hline & \multirow[t]{3}{*}{4} & $06 / 23$ & 7:00 / 10:00 / 13:00 / 16:00 / 19:00 & Feed / microingredients \\
\hline & & $06 / 25$ & $8: 00 / 11: 00 / 14: 00 / 17: 00 / 20: 00$ & Corn grains \\
\hline & & $06 / 27$ & $6: 00 / \quad 9: 00 / 12: 00 / 15: 00 / 18: 00$ & Soybean / animal meals \\
\hline \multirow{12}{*}{ July } & \multirow[t]{3}{*}{1} & 07/07 & 7:00 / 10:00 / 13:00 / 16:00 / 19:00 & Meals \\
\hline & & 07/09 & $8: 00 / 11: 00 / 14: 00 / 17: 00 / 20: 00$ & Feed / microingredients \\
\hline & & $07 / 11$ & $6: 00 / \quad 9: 00 / 12: 00 / 15: 00 / 18: 00$ & Corn grains \\
\hline & \multirow[t]{3}{*}{2} & $07 / 14$ & 7:00 / 10:00 / 13:00 / 16:00 / 19:00 & Corn grains \\
\hline & & $07 / 16$ & $8: 00 / 11: 00 / 14: 00 / 17: 00 / 20: 00$ & Soybean / animal meals \\
\hline & & $07 / 18$ & 6:00 / 9:00 / 12:00 / 15:00 / 18:00 & Feed / microingredients \\
\hline & \multirow[t]{3}{*}{3} & $07 / 21$ & 7:00 / 10:00 / 13:00 / 16:00 / 19:00 & Feed / microingredients \\
\hline & & $07 / 23$ & $8: 00 / 11: 00 / 14: 00 / 17: 00 / 20: 00$ & Corn grains \\
\hline & & $07 / 25$ & $6: 00 / \quad 9: 00 / 12: 00 / 15: 00 / 18: 00$ & Soybean / animal meals \\
\hline & \multirow[t]{3}{*}{4} & $07 / 27$ & 7:00 / 10:00 / 13:00 / 16:00 / 19:00 & Soybean / animal meals \\
\hline & & $07 / 29$ & $8: 00 / 11: 00 / 14: 00 / 17: 00 / 20: 00$ & Feed / microingredients \\
\hline & & $07 / 31$ & $6: 00 / \quad 9: 00 / 12: 00 / 15: 00 / 18: 00$ & Corn grains \\
\hline \multirow{12}{*}{ August } & \multirow[t]{3}{*}{1} & $08 / 04$ & 7:00 / 10:00 / 13:00 / 16:00 / 19:00 & Corn grains \\
\hline & & $08 / 06$ & $8: 00 / 11: 00 / 14: 00 / 17: 00 / 20: 00$ & Soybean / animal meals \\
\hline & & 08/08 & $6: 00 / \quad 9: 00 / 12: 00 / 15: 00 / 18: 00$ & Feed / microingredients \\
\hline & \multirow[t]{3}{*}{2} & $08 / 11$ & 7:00 / 10:00 / 13:00 / 16:00 / 19:00 & Feed / microingredients \\
\hline & & $08 / 13$ & $8: 00 / 11: 00 / 14: 00 / 17: 00 / 20: 00$ & Corn grains \\
\hline & & $08 / 15$ & 6:00 / 9:00 / 12:00 / 15:00 / 18:00 & Soybean / animal meals \\
\hline & \multirow[t]{3}{*}{3} & $08 / 18$ & 7:00 / 10:00 / 13:00 / 16:00 / 19:00 & Soybean / animal meals \\
\hline & & $08 / 20$ & $8: 00 / 11: 00 / 14: 00 / 17: 00 / 20: 00$ & Feed / microingredients \\
\hline & & $08 / 22$ & $6: 00 / \quad 9: 00 / 12: 00 / 15: 00 / 18: 00$ & Corn grains \\
\hline & \multirow[t]{3}{*}{4} & $08 / 25$ & 7:00 / 10:00 / 13:00 / 16:00 / 19:00 & Corn grains \\
\hline & & $08 / 27$ & $8: 00 / 11: 00 / 14: 00 / 17: 00 / 20: 00$ & Soybean / animal meals \\
\hline & & $08 / 29$ & $6: 00 / \quad 9: 00 / 12: 00 / 15: 00 / 18: 00$ & Feed / microingredients \\
\hline
\end{tabular}


per sector we considered the type of product, the equipment operating time and the total area of the sector. In the corn reception and pre-cleaning sectors six sampling points were defined, however, for corn drying four points were selected and for the storage sector forty eight points. In the soybean meal reception sector samples were collected at three points, and in the storage at sector seventeen points. Eighteen points were defined in the micro ingredients sectors. Quantification of product losses per equipment was performed specifically for each type of product, transport capacity of the equipments, operating time and total equipment area.

For the corn reception and storage equipment samples were obtained from thirty four different points, for the soybean meal reception and storage equipment samples were collected at ten points, while for the feed transport equipment eight points were sampled. Tarps measuring $1 \mathrm{~m}^{2}$ were used to determine losses at each point. The total product weight represented product losses on the mill floor.

The results were calculated for the total area, per sector and equipment, estimating the total product losses. This process was repeated five times on the same day for different operational times, different days and weeks during four months (Table 1). The product loss data was analyzed in spreadsheets, showing quantities and costs according to the equations below:

Table 2. Equations formulated for evaluation of product loss

\begin{tabular}{cc}
\hline Equation & Measurements \\
$L=\frac{C t}{A} \times P$ & bucket elevator \\
$L=\frac{C t}{l} \times P$ & conveyor belt and screw conveyor \\
$\mathrm{L}=\frac{\mathrm{Ct}}{\mathrm{A}} \times \mathrm{P}+(\mathrm{K}-\mathrm{Q})$ & pre cleaning machine \\
$L=\frac{(Q e \times U e)-(Q s \times U s)}{A}$ & storage silo \\
$\mathrm{L}=\frac{Q e-Q s}{T}$ & metering, mixer, expedition \\
$L=\frac{(Q e \times U e)-(Q s \times U s)}{T}$ & pelletizer \\
$D=\sum_{k=0}^{n} \mathrm{~V} \times \mathrm{Pt}$ & costs of the losses
\end{tabular}

wherein,

L: total product losses, $\mathrm{kg}$;

$\mathrm{Ct}$ : total capacity, $\mathrm{kg} \mathrm{h}^{-1}$;

$\mathrm{P}$ : losses of products, $\mathrm{kg} \mathrm{m}^{-2}$;

A: area, $\mathrm{m}^{2}$;

$1:$ length, $\mathrm{m}$;

$\mathrm{K}$ : quantity of products that entered the pre cleaning machine, $\mathrm{kg}$

$\mathrm{Q}$ : quantity of products that exited the pre cleaning machine, $\mathrm{kg}$

Qe : quantity of products that entered in the equipment, $\mathrm{kg}$

Qs : quantity of products that exited in the equipment, $\mathrm{kg}$

$\mathrm{T}:$ time, $\mathrm{h}$

Ue : initial moisture content, \% w.b.

Us : final moisture content, \% w.b.

$\mathrm{D}:$ costs of the product losses, US\$

$\mathrm{V}$ : product price, US\$

$\mathrm{Pt}$ : total product losses, $\mathrm{kg}$ 
Samples of the lost products from each sector of production and equipment were collected once per week for determination of water content and analysis of fungi and bacteria colonies, mites and insects.

The moisture content of corn (\% w.b.) was determined using the indirect method with the Geole moisture meter (G-800) after that equipment was calibrated using the official oven method at $103{ }^{\circ} \mathrm{C} \pm 2{ }^{\circ} \mathrm{C}$ for $24 \mathrm{~h}$. Tests were performed with $50 \mathrm{~g}$ samples in three replicates according to recommendations in the Rules for Seed Analysis (BRASIL, 2009). For determination of moisture content in flours and feeds of animal origin weighing of flasks was performed, previously cleaned and dried in an oven at $105^{\circ} \mathrm{C}$ for one hour and cooled in a desiccators until room temperature. A sample of $5 \mathrm{~g}$ was weighed and placed in an oven preheated to $103{ }^{\circ} \mathrm{C} \pm 2{ }^{\circ} \mathrm{C}$ until reaching constant weight (4 hours). Next, the container was removed from the oven, cooled in desiccators until reaching equilibrium with the ambient temperature, and weighed (AAFCO, 2003). For each sample three replicates were performed.

The assessment of whole insects and insect fragments in the products was performed by visual counting in $1 \mathrm{~kg}$ of the sampled product. The sampled product was poured on a table, with artificial lighting, and then all insects and insect fragments were removed with tweezers for counting.
Examination of mites was conducted by sieving through stainless steel mesh opening of $0.50 \mathrm{~mm}$ on a sheet of paper to separate the dust mite particles. The mites were quantified under a stereomicroscope (HUGHES, 1976). All results were expressed in terms of $50 \mathrm{~g}$ of sample. The analysis of toxigenic fungi was performed according to Dhingra and Sinclair (1995). However, counting of the bacterial colonies was performed in accordance with methods of the American Public Health Association-A.P.H.A (1992). The analyses were performed in triplicate and results were expressed as Colony Forming Unit per gram $\left.(\mathrm{CFU} \mathrm{g})^{-1}\right)$ of products.

\section{RESULTS AND DISCUSSION}

The lack of production quality leads to premature failure of equipment, not as a matter of intrinsic quality of the equipment, but as incorrect operational action which leads to immediate production losses. Increases in maintenance quality should be considered with the increase of technical staff and also by establishing standard procedures for performing and complying with all criteria and specific standards and regulations. Figure 2 characterizes utilization and application of the maintenance system in transport equipment of a feed mill.

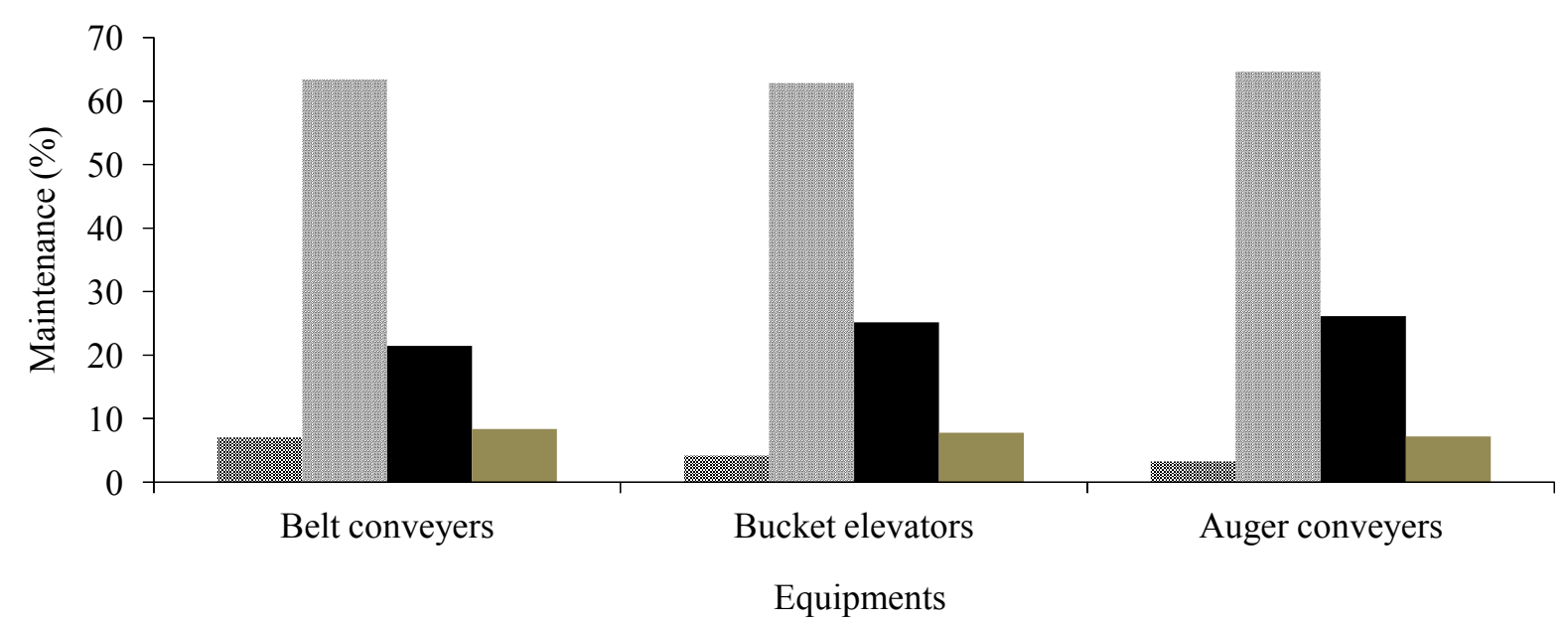

Maintenance performed within the time scheduled $\quad$ Maintenances missed within the time scheduled

Maintenance not performed

- Early maintenances

Figure 2. Evaluation of maintenance (\%) on equipments in the feed mill.

110 REVENG

105-118p. ENGENHARIA NA AGRICULTURA, VIÇOSA - MG, V.23 N.2, MARÇO / ABRIL 2015 
Table 3. Losses of corn grains in the transport equipment for the reception and storage sectors

\begin{tabular}{|c|c|c|c|c|c|}
\hline Equipment & $\begin{array}{l}\text { Area } \\
\left(\mathrm{m}^{2}\right)\end{array}$ & $\begin{array}{c}\text { Losses } \pm \text { SD } \\
\left(\mathrm{kg} \mathrm{m}^{-2}\right)\end{array}$ & $\begin{array}{c}\text { Total losses } \pm \text { SD } \\
(\mathrm{kg})\end{array}$ & Total $(\%)$ & $\begin{array}{c}\operatorname{Costs}^{1} \pm \mathrm{SD} \\
\left(\mathrm{US} \$ \mathrm{~h}^{-1}\right)\end{array}$ \\
\hline Bucket elevator 1 & 7.5 & $0.176 \pm 0.010$ & $1.322 \pm 0.075$ & 5.60 & $0.271 \pm 0.015$ \\
\hline Bucket elevator 2 & 7.5 & $0.183 \pm 0.008$ & $1.373 \pm 0.060$ & 5.82 & $0.281 \pm 0.012$ \\
\hline Bucket elevator 3 & 7.5 & $0.192 \pm 0.011$ & $1.442 \pm 0.083$ & 6.11 & $0.296 \pm 0.017$ \\
\hline Bucket elevator 4 & 7.5 & $0.161 \pm 0.012$ & $1.204 \pm 0.090$ & 5.10 & $0.247 \pm 0.018$ \\
\hline Bucket elevator 6 & 7.5 & $0.195 \pm 0.009$ & $1.461 \pm 0.068$ & 6.19 & $0.299 \pm 0.014$ \\
\hline Bucket elevator 7 & 7.5 & $0.171 \pm 0.010$ & $1.283 \pm 0.075$ & 5.43 & $0.263 \pm 0.015$ \\
\hline Bucket elevator 8 & 7.5 & $0.301 \pm 0.020$ & $2.256 \pm 0.150$ & 9.55 & $0.462 \pm 0.031$ \\
\hline Bucket elevator 9 & 7.5 & $0.184 \pm 0.013$ & $1.380 \pm 0.098$ & 5.84 & $0.283 \pm 0.020$ \\
\hline Bucket elevator 10 & 7.5 & $0.141 \pm 0.014$ & $1.058 \pm 0.105$ & 4.48 & $0.217 \pm 0.022$ \\
\hline Bucket elevator 11 & 7.5 & $0.175 \pm 0.016$ & $1.316 \pm 0.120$ & 5.57 & $0.269 \pm 0.025$ \\
\hline Belt conveyer 1 & 8.0 & $0.032 \pm 0.008$ & $0.256 \pm 0.064$ & 1.08 & $0.052 \pm 0.013$ \\
\hline Belt conveyer 2 & 35.0 & $0.013 \pm 0.002$ & $0.445 \pm 0.070$ & 1.88 & $0.091 \pm 0.014$ \\
\hline Belt conveyer 3 & 35.0 & $0.041 \pm 0.009$ & $1.422 \pm 0.315$ & 6.11 & $0.292 \pm 0.064$ \\
\hline Belt conveyer 4 & 8.0 & $0.028 \pm 0.006$ & $0.224 \pm 0.048$ & 0.95 & $0.046 \pm 0.009$ \\
\hline Belt conveyer 5 & 35.0 & $0.015 \pm 0.004$ & $0.523 \pm 0.140$ & 2.22 & $0.107 \pm 0.029$ \\
\hline Belt conveyer 6 & 35.0 & $0.014 \pm 0.003$ & $0.484 \pm 0.105$ & 2.05 & $0.099 \pm 0.022$ \\
\hline Belt conveyer 7 & 15.0 & $0.031 \pm 0.010$ & $0.466 \pm 0.150$ & 1.97 & $0.095 \pm 0.031$ \\
\hline Belt conveyer 8 & 22.0 & $0.019 \pm 0.007$ & $0.414 \pm 0.154$ & 1.75 & $0.084 \pm 0.031$ \\
\hline Belt conveyer 9 & 17.0 & $0.037 \pm 0.005$ & $0.628 \pm 0.085$ & 2.66 & $0.129 \pm 0.017$ \\
\hline Belt conveyer 10 & 24.0 & $0.027 \pm 0.007$ & $0.638 \pm 0.168$ & 2.70 & $0.131 \pm 0.034$ \\
\hline Belt conveyer 11 & 22.0 & $0.022 \pm 0.005$ & $0.493 \pm 0.110$ & 2.09 & $0.101 \pm 0.023$ \\
\hline Belt conveyer 12 & 22.0 & $0.031 \pm 0.006$ & $0.678 \pm 0.132$ & 2.87 & $0.139 \pm 0.027$ \\
\hline Belt conveyer 13 & 9.0 & $0.017 \pm 0.005$ & $0.156 \pm 0.045$ & 0.66 & $0.032 \pm 0.009$ \\
\hline Belt conveyer 14 & 9.0 & $0.016 \pm 0.003$ & $0.143 \pm 0.027$ & 0.61 & $0.348 \pm 0.005$ \\
\hline Belt conveyer 15 & 9.0 & $0.016 \pm 0.004$ & $0.141 \pm 0.036$ & 0.60 & $0.029 \pm 0.007$ \\
\hline Belt conveyer 16 & 9.0 & $0.021 \pm 0.004$ & $0.187 \pm 0.036$ & 0.79 & $0.038 \pm 0.007$ \\
\hline Auger conveyer 1 & 22.0 & $0.036 \pm 0.008$ & $0.787 \pm 0.176$ & 3.33 & $0.161 \pm 0.036$ \\
\hline Auger conveyer 2 & 22.0 & $0.031 \pm 0.007$ & $0.691 \pm 0.154$ & 2.93 & $0.141 \pm 0.032$ \\
\hline Auger conveyer 3 & 9.0 & $0.014 \pm 0.003$ & $0.126 \pm 0.027$ & 0.53 & $0.026 \pm 0.005$ \\
\hline Auger conveyer 4 & 9.0 & $0.017 \pm 0.004$ & $0.156 \pm 0.036$ & 0.66 & $0.032 \pm 0.007$ \\
\hline Auger conveyer 5 & 9.0 & $0.017 \pm 0.005$ & $0.152 \pm 0.045$ & 0.64 & $0.031 \pm 0.009$ \\
\hline Auger conveyer 6 & 9.0 & $0.017 \pm 0.006$ & $0.154 \pm 0.054$ & 0.65 & $0.032 \pm 0.011$ \\
\hline Auger conveyer 7 & 7.5 & $0.020 \pm 0.007$ & $0.152 \pm 0.053$ & 0.64 & $0.031 \pm 0.011$ \\
\hline Total & & & $23.610 \pm 0.671$ & 100 & $5.155 \pm 0.642$ \\
\hline
\end{tabular}

${ }^{1}$ Average price per kilogram of corn (240 samples) (BM\&F, 2008) was US\$ 0.205. Evaluation performed for 1 hour of equipment operation (flow 60 ton $\mathrm{h}^{-1}$ of products). SD (Standard Deviation).

Product losses per equipment of the feed mill are presented in Table 3. The percent of corn losses in the bucket elevators represented $60 \%$. Belt conveyers were responsible for approximately $80 \%$ of total soybean meal losses. In the feed production process the product losses were highest in the bucket elevators, reaching $72.39 \%$ (Table 4). The function of these equipment is to interconnect structures and machinery by moving the product mass in vertical, horizontal and inclined directions.
To perform these functions it is essential to carry out carefully planned and executed maintenance, minimizing the chance of equipment breakage, reducing lost time due to interruptions and product losses.

For this, bucket elevators should be inspected for heat stains due to friction between the belt and rollers, and observe noises of friction between the cups and the structure of the carrier. 
Table 4. Soybean meal losses in the transport equipment for the receiving and storage areas of the feed mill

\begin{tabular}{lccccc}
\hline Equipment & $\begin{array}{c}\text { Area } \\
\left(\mathrm{m}^{2}\right)\end{array}$ & $\begin{array}{c}\text { Losses }{ }^{ \pm} \mathrm{SD} \\
\left(\mathrm{kg} \mathrm{m}^{-2}\right)\end{array}$ & $\begin{array}{c}\text { Total losses } \pm \mathrm{SD} \\
(\mathrm{kg})\end{array}$ & $\begin{array}{c}\text { Total } \\
(\%)\end{array}$ & $\begin{array}{c}\text { Costs }^{1 \pm} \mathrm{SD} \\
\left(\mathrm{USS}^{-1}\right)\end{array}$ \\
\hline Bucket elevator 1 & 7.5 & $0.082 \pm 0.020$ & $0.618 \pm 0.150$ & 6.18 & $0.222 \pm 0.054$ \\
Belt conveyer 1 & 16.5 & $0.071 \pm 0.016$ & $1.176 \pm 0.264$ & 11.76 & $0.423 \pm 0.095$ \\
Belt conveyer 2 & 17.5 & $0.076 \pm 0.021$ & $1.337 \pm 0.368$ & 13.37 & $0.481 \pm 0.132$ \\
Belt conveyer 3 & 21.0 & $0.075 \pm 0.024$ & $1.578 \pm 0.504$ & 15.78 & $0.568 \pm 0.181$ \\
Belt conveyer 4 & 12.5 & $0.081 \pm 0.014$ & $1.017 \pm 0.175$ & 10.08 & $0.366 \pm 0.063$ \\
Belt conveyer 5 & 14.4 & $0.072 \pm 0.023$ & $1.033 \pm 0.331$ & 10.33 & $0.372 \pm 0.119$ \\
Belt conveyer 6 & 13.0 & $0.084 \pm 0.012$ & $1.092 \pm 0.156$ & 10.92 & $0.393 \pm 0.056$ \\
Belt conveyer 7 & 7.8 & $0.080 \pm 0.021$ & $0.625 \pm 0.164$ & 6.25 & $0.225 \pm 0.059$ \\
Auger conveyer 1 & 10.0 & $0.071 \pm 0.018$ & $0.714 \pm 0.180$ & 7.14 & $0.257 \pm 0.065$ \\
Auger conveyer 2 & 10.0 & $0.081 \pm 0.017$ & $0.809 \pm 0.170$ & 8.09 & $0.291 \pm 0.061$ \\
\hline Total & & & $10.000 \pm 2.462$ & 100 & $3.124 \pm 0.885$ \\
\hline
\end{tabular}

${ }^{1}$ Average price per kilogram of soybean meal (240 samples) (BM\&F, 2008) was US\$ 0.360. Evaluation performed for 1 hour of equipment operation (flow 60 ton $^{-1}$ of products). SD (Standard Deviation).

Table 5. Product losses in transport equipment of feed production in the feed mill

\begin{tabular}{lccccc}
\hline Equipment & $\begin{array}{c}\text { Area } \\
\left(\mathrm{m}^{2}\right)\end{array}$ & $\begin{array}{c}\text { Losses } \pm \mathrm{SD} \\
\left(\mathrm{kg} \mathrm{m}^{-2}\right)\end{array}$ & $\begin{array}{c}\text { Total losses } \pm \text { SD } \\
(\mathrm{kg})\end{array}$ & $\begin{array}{c}\text { Total } \\
(\%)\end{array}$ & $\begin{array}{c}\text { Costs } \pm \text { SD } \\
\left(\mathrm{US} \$ \mathrm{~h}^{-1}\right)\end{array}$ \\
\hline${ }^{1}$ Bucket elevator 1 & 6.25 & $0.797 \pm 0.145$ & $4.984 \pm 0.906$ & 28.94 & $1.535 \pm 0.279$ \\
${ }^{2}$ Bucket elevator 2 & 6.25 & $0.231 \pm 0.087$ & $1.446 \pm 0.544$ & 8.40 & $0.505 \pm 0.199$ \\
${ }^{1}$ Bucket elevator 3 & 6.25 & $0.528 \pm 0.104$ & $3.299 \pm 0.650$ & 19.15 & $1.012 \pm 0.199$ \\
${ }^{1}$ Bucket elevator 4 & 6.25 & $0.438 \pm 0.101$ & $2.739 \pm 0.631$ & 15.90 & $0.841 \pm 0.194$ \\
${ }^{1}$ Auger conveyer 1 & 3.00 & $0.178 \pm 0.047$ & $0.535 \pm 0.141$ & 3.11 & $0.164 \pm 0.043$ \\
${ }^{3}$ Auger conveyer 2 & 3.00 & $0.374 \pm 0.087$ & $1.121 \pm 0.261$ & 7.02 & $0.317 \pm 0.074$ \\
${ }^{3}$ Auger conveyer 3 & 3.00 & $0.231 \pm 0.076$ & $0.694 \pm 0.228$ & 4.03 & $0.196 \pm 0.064$ \\
${ }^{4}$ Auger conveyer 4 & 3.00 & $0.205 \pm 0.064$ & $0.616 \pm 0.192$ & 3.58 & $0.174 \pm 0.054$ \\
${ }^{1}$ Auger conveyer 5 & 3.00 & $0.154 \pm 0.042$ & $0.461 \pm 0.126$ & 2.68 & $0.142 \pm 0.039$ \\
${ }^{5}$ Auger conveyer 6 & 6.00 & $0.110 \pm 0.036$ & $0.660 \pm 0.216$ & 3.83 & $0.203 \pm 0.066$ \\
${ }^{5}$ Auger conveyer 7 & 3.00 & $0.116 \pm 0.040$ & $0.347 \pm 0.120$ & 2.01 & $0.106 \pm 0.037$ \\
${ }^{5}$ Auger conveyer 8 & 3.00 & $0.107 \pm 0.033$ & $0.322 \pm 0.099$ & 1.87 & $0.099 \pm 0.030$ \\
\hline Total & & & $17.222 \pm 4.114$ & 100 & $5.294 \pm 1.278$ \\
\hline
\end{tabular}

Average price per kilogram (BM\&F, 2008): ${ }^{1}$ for all the products (US\$ 0.307), ${ }^{2}$ vegetal meals (US\$ 0.349), ${ }^{3}$ corn (US\$ 0.283 ), ${ }^{4}$ animal meals (US\$ 0.283), ${ }^{5}$ feed (US\$ 0.307). Evaluation performed for 1 hour of equipment operation (flow 60 ton $\mathrm{h}^{-1}$ of products). SD (Standard Deviation). (240 samples).

Preventive maintenance is important to confirm that the belt is properly stretched and buckets are aligned, replace the damaged buckets, repair damage at the seams and straps, tighten loose screws, lubricate bearings and gear units as specified by the manufacturer or replace damaged bearings with exhausted useful life and verify the correct operation of safety devices. In maintenance of belt conveyors to reduce product losses in transport, it is recommended to check the belt for cutting damage, observe the alignment, check the condition of bearings and bushings, replace damaged rollers and adjust the belt tension. In the case of screw conveyors (Table 5) the conditions of bearings, alignment, and the state of the helical trough must be assessed.

Figure 3 represent the results of the maintenance system applied in the external sectors of the feed industry.

\section{REVENG}


According to Figure $3,40 \%$ to $70 \%$ of machinery maintenance in all sectors of the feed plant are not performed at the scheduled time, between $3 \%$ and $25 \%$ of maintenance is not performed, while less than $30 \%$ is conducted on time. Approximately $20 \%$ of the equipment maintenance is anticipated. Tables 6 and 7 present the results of the losses and total costs of corn and soybean meal determined for the external sector of the feed mill. For corn grain, $82 \%$ of loss occurs in the reception area. However, for soybean meal the storage silos presented greatest losses, comprising $78 \%$. The importance of a well maintained installation, with few interruptions, allows for obtaining a competitive advantage over competitors (CORADI et al., 2009).

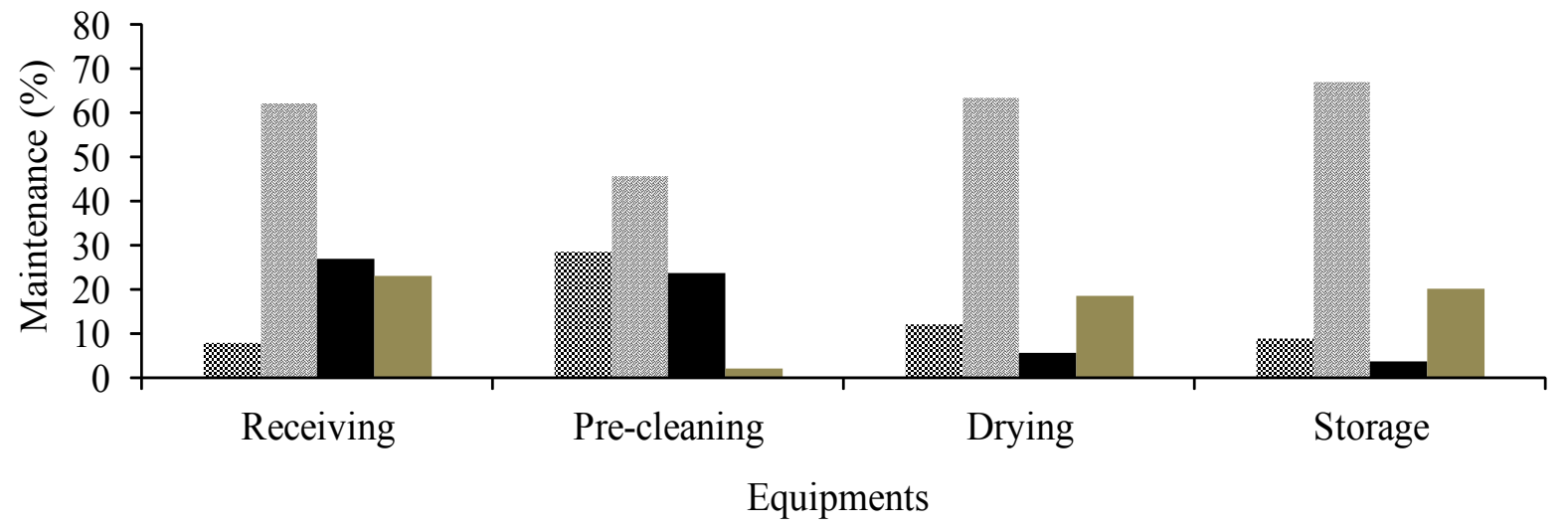

Maintenance performed within the time scheduled Maintenances missed within the time scheduled

- Maintenance not performed Early maintenances

Figure 3. Maintenance (\%) in the external sectors of the feed mill.

Table 6. Corn losses in the external sectors of the feed mill

\begin{tabular}{lccccc}
\hline Sectors & Area $\left(\mathrm{m}^{2}\right)$ & $\begin{array}{c}\text { Losses } \pm \mathrm{SD} \\
\left(\mathrm{kg} \mathrm{m}^{2}\right)\end{array}$ & $\begin{array}{c}\text { Total losses } \\
\pm \mathrm{SD}(\mathrm{kg})\end{array}$ & $\begin{array}{c}\text { T o t a } 1 \\
(\%)\end{array}$ & $\begin{array}{c}\text { Costs }^{1 \pm S D} \\
\left(\mathrm{US} \$ \mathrm{~h}^{-1}\right)\end{array}$ \\
\hline Receiving & 1071 & $0.652 \pm 0.128$ & $36.899 \pm 7.584$ & 82.32 & $7.564 \pm 1.554$ \\
Pre-cleaning & 36 & $0.015 \pm 0.024$ & $0.554 \pm 0.864$ & 1.24 & $0.113 \pm 0.177$ \\
Drying & 34 & $0.018 \pm 0.003$ & $0.598 \pm 0.102$ & 1.33 & $0.122 \pm 0.021$ \\
Storage & 1058 & $0.006 \pm 0.002$ & $6.771 \pm 2.116$ & 15.11 & $1.388 \pm 0.434$ \\
\hline Total & & & $44.822 \pm 10.666$ & 100 & $9.065 \pm 2.186$ \\
\hline
\end{tabular}

${ }^{1}$ Average price per kilogram of corn (240 samples) (BM\&F, 2008) was US\$ 0.205. Evaluation performed for 1 hour of operation in the sector (flow 60 ton $\mathrm{h}^{-1}$ of products). SD (Standard Deviation). (240 samples).

Table 7. Soybean meal losses in the external sectors of the feed mill

\begin{tabular}{lccccc}
\hline Sectors & $\begin{array}{c}\text { Area } \\
\left(\mathrm{m}^{2}\right)\end{array}$ & $\begin{array}{c}\text { Losses } \\
\left(\mathrm{kg} \mathrm{m}^{-2}\right)\end{array}$ & $\begin{array}{c}\text { Total losses } \\
\pm \mathrm{SD}(\mathrm{kg})\end{array}$ & $\begin{array}{c}\text { Total } \\
(\%)\end{array}$ & $\begin{array}{c}\text { Costs }^{1 \pm \mathrm{SD}} \\
\left({\left.\mathrm{US} \$ \mathrm{~h}^{-1}\right)}^{2}\right.\end{array}$ \\
\hline Receiving & 171 & $0.036 \pm 0.005$ & $3.652 \pm 0.531$ & 21.88 & $1.315 \pm 0.191$ \\
Storage & 695 & $0.036 \pm 0.005$ & $12.916 \pm 1.790$ & 78.11 & $4.649 \pm 0.644$ \\
\hline Total & & & $16.535 \pm 2.321$ & 100 & $5.964 \pm 0.835$ \\
\hline
\end{tabular}

${ }^{1}$ Average price per kilogram (BM\&F, 2008) was US\$ 0.360. Evaluation performed for 1 hour of operation in the sector (flow 60 ton $\mathrm{h}^{-1}$ of products). SD (Standard Deviation). (240 samples). 


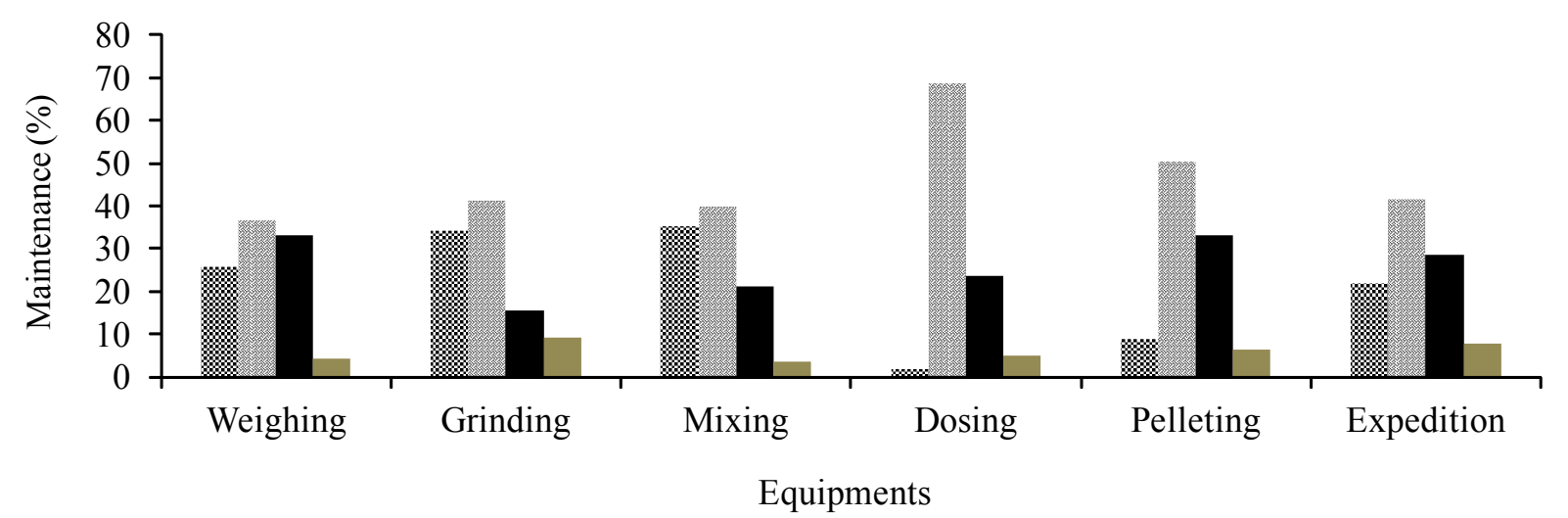

Maintenance performed within the time scheduled
$\begin{array}{ll}\text { - Maintenance not performed } & \text { Early maintenances }\end{array}$

Figure 4. Maintenance (\%) in the internal sectors of the feed mill.

To reduce the product losses in pre-cleaning the machines must be adjusted for speed and inclination of vibrating sieves, bearings at the end of the useful life must be replaced, air leaks should be repaired and appropriate screens according to the type of product should be used. The storage silos, dryers and material receiving systems should be cleaned constantly, avoiding generation of toxic gases, pests and rodents. Equipment and accessories must be free of any obstruction to ensure flow of products. Figure 4 presents the analysis of the internal sectors of the industry.

In all internal sectors of the feed mill high indices of maintenance not performed at the scheduled time were observed ( $68 \%$ for the dosing sector) (Table 8). When compared with the external sectors the machinery of the factory production area showed to be in better condition. Maintenance not performed did not exceed $30 \%$ of the total, while anticipated maintenance did not surpass $10 \%$. All maintenance performed at the scheduled time was between $10 \%$ and $35 \%$. Significant products losses were observed in the dosing sector (Table 7); however, the high cost of the premixes caused the largest economic loss of all processes evaluated.

Given that production costs are increasingly high and profit margins are relatively low, it is important to avoid losses in production systems, even though they are almost insignificant with regards to the total production of a factory. These costs, when analyzed at the end of one month or one year's production, are relevant and will certainly force the industry to rethink its policy of quality management for implementation of a better equipment maintenance program by perfuming scheduled stops and investing in training and hiring of qualified personnel. This was have an initial costs, but is easily recovered with the gain in production, quality and profits over time. The Brazilian Association of Maintenance (CORADI et al., 2009) highlights that $4.21 \%$ of company gross sales account for maintenance costs, representing expenses of approximately US\$ 30 billion per year. The two largest contributing factors in the costs of conservation are manpower (35.46\%), and replacement of materials (33.92\%). The source of the research also reports that $25.53 \%$ of maintenance is corrective and preventive maintenance accounts for $28.75 \%$. Experiments have shown that $60 \%$ to $75 \%$ of the total life cycles of repairable systems are associated with upkeep.

Overall, $28 \%$ of the final cost of the manufactured product is spent on conservation activities in production systems. Although the maintenance costs of machinery and equipment are high, when considering the total product losses (Table 9) observed there are advantages in adopting measures to control and monitor the failures of repairable products.

The physical product losses for the mill caused by inadequate equipment and machinery

\section{REVENG}


Table 8. Product losses in the internal sectors of the feed mill

\begin{tabular}{|c|c|c|c|c|c|}
\hline Sectors & Area $\left(\mathrm{m}^{2}\right)$ & $\begin{array}{c}\text { Losses } \\
\pm \mathrm{SD}\left(\mathrm{kg} \mathrm{m}^{-2}\right)\end{array}$ & $\begin{array}{l}\text { Total losses } \\
\pm \mathrm{SD}(\mathrm{kg})\end{array}$ & $\begin{array}{c}\text { Total } \\
(\%) \\
\end{array}$ & $\begin{array}{c}\text { Costs } \\
\pm \mathrm{SD}\left(\mathrm{US} \$ \mathrm{~h}^{-1}\right)\end{array}$ \\
\hline${ }^{6}$ Weighing & 32.50 & $0.026 \pm 0.009$ & $0.837 \pm 0.293$ & 10.45 & $0.096 \pm 0.034$ \\
\hline${ }^{7}$ Weighing & 10.20 & $0.016 \pm 0.004$ & $0.161 \pm 0.041$ & 2,01 & $0.300 \pm 0.076$ \\
\hline${ }^{8}$ Weighing & 20.30 & $0.010 \pm 0.002$ & $0.194 \pm 0.041$ & 2.42 & $6.786 \pm 1.434$ \\
\hline${ }^{2}$ Reception & 9.40 & $0.080 \pm 0.018$ & $0.752 \pm 0.169$ & 9.40 & $0.262 \pm 0.058$ \\
\hline${ }^{9}$ Dosing & 8.35 & $0.013 \pm 0.003$ & $0.109 \pm 0.025$ & 1.36 & $0.013 \pm 0.002$ \\
\hline${ }^{4}$ Dosing & 8.35 & $0.066 \pm 0.022$ & $0.549 \pm 0.184$ & 6.85 & $0.155 \pm 0.052$ \\
\hline${ }^{4}$ Dosing & 8.35 & $0.038 \pm 0.010$ & $0.314 \pm 0.084$ & 3.92 & $0.088 \pm 0.024$ \\
\hline${ }^{4}$ Dosing & 8.35 & $0.060 \pm 0.025$ & $0.498 \pm 0.219$ & 6.22 & $0.141 \pm 0.062$ \\
\hline${ }^{2}$ Dosing & 8.35 & $0.148 \pm 0.050$ & $1.240 \pm 0.428$ & 15.48 & $0.432 \pm 0.149$ \\
\hline${ }^{3}$ Dosing & 8.35 & $0.106 \pm 0.034$ & $0.888 \pm 0.284$ & 11.08 & $0.251 \pm 0.080$ \\
\hline${ }^{2}$ Dosing & 8.35 & $0.017 \pm 0.005$ & $0.146 \pm 0.042$ & 1.82 & $0.051 \pm 0.015$ \\
\hline${ }^{4}$ Dosing & 8.35 & $0.021 \pm 0.007$ & $0.176 \pm 0.058$ & 2.19 & $0.050 \pm 0.016$ \\
\hline${ }^{1}$ Adition & 3.60 & $0.064 \pm 0.022$ & $0.230 \pm 0.079$ & 2.87 & $0.071 \pm 0.024$ \\
\hline${ }^{1}$ Mixing & 2.50 & $0.078 \pm 0.020$ & $0.195 \pm 0.050$ & 2.43 & $0.060 \pm 0.015$ \\
\hline${ }^{1}$ Grinding & 3.40 & $0.076 \pm 0.023$ & $0.259 \pm 0.078$ & 3.23 & $0.080 \pm 0.024$ \\
\hline${ }^{1}$ Grinding & 9.70 & $0.036 \pm 0.013$ & $0.352 \pm 0.126$ & 4.39 & $0.108 \pm 0.039$ \\
\hline${ }^{5}$ Pelletization & 15.40 & $0.032 \pm 0.008$ & $0.493 \pm 0.123$ & 6.15 & $0.151 \pm 0.038$ \\
\hline${ }^{5}$ Expedition & 10.24 & $0.010 \pm 0.003$ & $0.106 \pm 0.031$ & 1.32 & $0.032 \pm 0.009$ \\
\hline${ }^{5}$ Expedition & 10.24 & $0.012 \pm 0.004$ & $0.123 \pm 0.041$ & 1.53 & $0.036 \pm 0.012$ \\
\hline${ }^{5}$ Expedition & 10.24 & $0.013 \pm 0.002$ & $0.134 \pm 0.020$ & 1.67 & $0.038 \pm 0.005$ \\
\hline${ }^{5}$ Expedition & 10.24 & $0.012 \pm 0.005$ & $0.120 \pm 0.051$ & 1.49 & $0.040 \pm 0.017$ \\
\hline${ }^{5}$ Expedition & 10.24 & $0.013 \pm 0.004$ & $0.135 \pm 0.041$ & 1.69 & $0.042 \pm 0.013$ \\
\hline Total & & & $8.009 \pm 2.508$ & 100 & $9.283 \pm 2.198$ \\
\hline
\end{tabular}

Average price per kilogram (BM\&F, 2008): ${ }^{1}$ for all the products (US\$ 0.307$),{ }^{2}$ vegetal meals (US\$ 0.349), ${ }^{3}$ corn (US\$ 0.283), ${ }^{4}$ animal meals (US\$ 0.283), ${ }^{5}$ feed (US\$ 0.307), ${ }^{6}$ Microingredients (US\$ 0.115), ${ }^{7}$ Lysine (US\$ 1.867), ${ }^{8}$ Premixes (US\$ 34.984), ${ }^{9}$ Oils (US\$ 0.116). Evaluations performed for 1 hour of operation in the sector (flow 60 ton. $\mathrm{h}^{-1}$ of products). SD (Standard Deviation). (240 samples).

Table 9. Total product losses in the feed mill

\begin{tabular}{llccc}
\hline Evaluation & Products & $\begin{array}{c}\text { Total } \\
\text { losses } \pm \text { SD }(\mathrm{kg})\end{array}$ & $\begin{array}{c}\text { Total losses } \\
(\%)\end{array}$ & $\begin{array}{c}\text { Total costs } \pm \text { SD } \\
\left(\text { US\$ } \mathrm{h}^{-1}\right)\end{array}$ \\
\hline Transport equipment & Corn grains & $23.610 \pm 0.671$ & 19.64 & $5.155 \pm 0.642$ \\
Transport equipment & Soybean meals & $10.000 \pm 2.462$ & 8.32 & $3.124 \pm 0.885$ \\
Transport equipment & Feed production & $17.222 \pm 4.114$ & 14.33 & $5.294 \pm 1.278$ \\
Sectors & Corn grains & $44.822 \pm 10.666$ & 37.30 & $9.065 \pm 2.186$ \\
Sectors & Soybean meals & $16.535 \pm 2.321$ & 13.76 & $5.964 \pm 0.835$ \\
Sectors & Feed production & $8.009 \pm 2.508$ & 6.66 & $9.283 \pm 2.198$ \\
\hline Total & & $120.198 \pm 22.742$ & 100 & $37.885 \pm 8.024$ \\
\hline
\end{tabular}

maintenance become even more relevant when observing the damage caused by poorly managed production units, reducing the quality of additional lots and contamination mixtures. The product losses are usually collected from the ground in the industry with high water content in a poor state of preservation with dirt or contamination. Among the types of contamination found in product samples are high levels of fungi, mites, insects and Salmonella sp. (Table 10). 
Table 10. Microbiological contamination in the losses products

\begin{tabular}{lccccc}
\hline Products & $\begin{array}{c}\text { Water } \\
\text { content }(\% \text { w.b. })\end{array}$ & Insects $\left(\mathrm{n}^{0}.\right)$ & Mites $\left(\mathrm{n}^{0}.\right)$ & $\begin{array}{c}\text { Fungi } \\
\left(\mathrm{CFU} \mathrm{g}^{-1}\right)\end{array}$ & $\begin{array}{c}\text { Salmonella sp. } \\
\left(\mathrm{CFU} \mathrm{g}^{-1}\right)\end{array}$ \\
\hline Corn grains & 17.7 & 16 & 15 & $6.8 \times 10^{4}$ & $1.2 \times 10^{2}$ \\
Vegetal meals & 18.5 & 12 & 12 & $7.4 \times 10^{4}$ & $4.3 \times 10^{2}$ \\
Flours animals & 17.4 & 7 & 8 & $5.3 \times 10^{3}$ & $5.7 \times 10^{3}$ \\
Microingredients & 16.2 & 6 & 6 & $4.6 \times 10^{2}$ & $3.9 \times 10^{2}$ \\
Feeds & 16.8 & 8 & 10 & $4.8 \times 10^{4}$ & $3.6 \times 10^{2}$ \\
\hline
\end{tabular}

Several authors have observed that increasing water content in the products can lead to deterioration and loss of dry matter over time. Quezada et al. (2006) reported a trend towards reducing the germination potential of the grain at an initial moisture content of $17 \%$ (w.b.) during storage. Costa et al. (2010) observed greater loss of germination percentage in stored corn grains with high water content when compared to dry stored grain, due to the increase of fungal infection rate. Coradi et al. (2014) reported that increased water content in maize caused a reduction in dry matter as a result of insect infestation in grains.

Temperature and relative humidity are directly associated with mold development in the products, where the best conditions for growth are between $20^{\circ} \mathrm{C}$ to $30^{\circ} \mathrm{C}$ and above $70 \%$, respectively. In corn grains a moisture content above $12 \%$ was adequate for fungi development, but in general, considering all products and by-products the acceptable limit was below $14 \%$. In the same conditions, for control and safety against fungi growth, the water activity must be below 0.65 . The high water contents reported in Table 9 justify the presence of microbiological contamination in the samples. These results are in accordance with Quezada et al. (2006), Costa et al. (2010) and Coradi et al. (2014). Therefore, the products are susceptible to the development of microorganisms, especially those of the species Penicillium chrysogenum, Aspergillus flavus and Rhizopus chizopodifarmis. Contamination decreases dry matter digestibility, amino acid, and vitamin and fat contents in feed (KESHAVARS ; AUSTIC, 2004; CORADI et al., 2011). Microbiological development, the production of mycotoxins and Salmonella species bacteria are among the main problems for animals
(DAVIES et al., 2004). Aflatoxin is due to the fact that they represent one of the most potential carcinogenic substances known so far in animals (FANDOHAN et al., 2005). Trout, ducklings and pigs are highly susceptible, while ruminants are less susceptible. According to the Food and Drug Administration (FDA, 2003), total annual costs of mycotoxins reached US\$932 million.

\section{CONCLUSION}

It was concluded from this study that:

- The maintenance system of the feed industry had a direct influence on product losses (120.198 $\left.\mathrm{kg} \mathrm{h}^{-1}\right)$ increasing the production cost to US\$37.885 per hour worked;

- The entire production system was compromised by microbiological contamination when the lost products were mixed in the lots of production.

\section{ACKNOWLEDGEMENTS}

The authors would like to thank the CAPES Foundation (Brazilian Ministry of Education), Department of the Agricultural Engineering and Federal University at Viçosa for their financial support.

\section{BIBLIOGRAFY REFERENCES}

AMERICAN PUBLIC HEALTH ASSOCIATION, A.P.H.A. Compendium of methods for the microbiological examination of foods. 3. ed. Washington, 1992. 701p.

ASSOCIATION OF AMERICAN FEED 
CONTROL OFFICIAL, AAFCO. Official Publication, Association of American Feed Control Official, 2003.

BENNET, J.W. \& KLICH, M. Mycotoxins. Clin. Microbiol. v.16, p.497-516, 2003.

BHATNAGAR, D.; PAYNE, G.A.; CLEVELAND, T.E.; ROBENS, J.F. Mycotoxins: current issues in USA. In: BARUG, D.; EGMOND, H.V.; LOPEZ-GARCIA, R.; OSENBRUGGEN, T.V.; VISCONTI, A. (Eds.), Meeting the Mycotoxin Menace. Wageningen Academic Publishers, p.1747, 2004.

BOLSA DE MERCADORIAS E FUTUROS, BM\&F. Cotações e gráficos, http://br.advfn.com, 2008.

MINISTÉRIO DA AGRICULTURA E REFORMA AGRÁRIA, BRASIL. Regras para Análise de Sementes. Brasília, DF, 2009.

BRERA, C.; DEBEGNACH, F.; GROSSI, S.; MIRAGLIA, M.. Effect of industrial processing on the distribution of fumonisin B1 in dry milling corn fractions. Journal Food Protection, v.67, p.1261-1266, 2004.

CORADI, P.C.; LACERDA FILHO, A.F.; MELO, E.C. Análise de Perigos e Pontos Críticos de Controle (APPCC) no processo de fabricação da ração. Revista Eletrônica Nutritime, v.6, p.10981102, 2009.

CORADI, P.C.; LACERDA FILHO, A.F.; MELO, E.C. Quality of raw materials from different regions of Minas Gerais State utilized in ration industry. Revista Brasileira de Engenharia Agrícola e Ambiental (Online), v.15, p.424-431, 2011.

CORADI, P.C.; CHAVES, J.B.P.; LACERDA FILHO, A.F.; MOTA, T.O. Quality of stored grain of corn in different conditions. Científica (Jaboticabal. Online), v.42, p.118-133, 2014.

COSTA, A.R.; FARONI. L.R.D.; ALENCAR, E.R.; CARVALHO, M.C.S.; FERREIRA, L.G.
Qualidade de grãos de milho armazenados em silos bolsa. Revista Ciência Agronômica, v.41, p.200207, 2010.

DAVIES, P.R.; HURD, H.S.; FUNK, J.A.; FEDORKA-CRAY, P.J; JONES, F.T. The role of contaminated feed in the epidemiology and control of Salmonella enterica in pork production. Foodborne Pathogens, p.202-215, 2004.

DHINGRA, O.D. \& SINCLAIR, J.B. Basic plant pathology methods. 2.ed. Boca Raton: CRC Press, 1995, 434p.

FANDOHAN, P.; ZOUMENOU, D.; HOUNHOUIGAN, D.J.; MARASAS, W.F.O.; WINGFIELD, M.J.; HELL, K. Fate of aflatoxins and fumonisins during the processing of maize into food products in Benin. Int. J. Food Microbiol. v.98, p.249-259, 2005.

FRAGA, M.E; CURVELLO, F.; GATTI, M.J.; CAVAGLIERI, L.R.; DALCERO, A.M.; ROSA, C.A.Potentialaflatoxin and ochratoxinAproduction by Aspergillus species in poultry feed processing, Veterinary Research Communications, v.31, p.343-353, 2007.

JARDINE, C. Perdas: quando a produção não vai para o saco. A Granja, v.58, p.12-21, 2002.

HUGHES, A.M. The mites of stored food and houses. Min. Agric. Fish. Food, London, 1976, 400p., 1976.

KESHAVARS, K. \& AUSTIC, R.E. The use of low protein, low phosphorus, amino acid - and phytase - supplement diets on laying hen performance and nitrogen and phosphorus extretion. Poultry Science, v.83, p.75-83, 2004.

KRSKA， R.; WELZIG, E.; BERTHILLER, F.; MOLINELLI, A.; MIZAIKOFF, B. 2005. Advances in the analysis of mycotoxins and its quality assurance. Food Additive Contaminant, v.22, p.345-353.

PETTERSSON, H. Controlling mycotoxins in 
animal feed. In: MAGAN, N.; OLSEN, M. (Eds.), Detection and Control. CRC Press, Woodhead Publishin Limited, England, p.262-304, 2004.

QUEZADA, M.Y.; MORENO, J.; VAZQUEZ, M.E.; MENDOZA, M.; MENDEZ-ALBORES, A.; MORENO-MARTINEZ, E. Hermetic storage system preventing the proliferation of Prostephanus truncatus Horn and storage fungi in maize with different moisture contents. Postharvest Biology and Technology, Oxford, v.39, n.3, p.321-326, 2006.

SCHATZMAYR, G.; ZEHNER, F.;
SCHATZMAYR, D.; TAUBEL, M.; BINDER, E. M. Microbiologicals for deactivating mycotoxins in contaminated feed. Mol. Nutr. Food Res. v.50, p.543-551, 2006.

WHITAKER, T.B. Standardization of mycotoxin sampling procedures: an urgent necessity. Food Control, v.14, p.233-237, 2003.

WU, F. Mycotoxins risk assessment for the purpose of setting international regulatory standards. Environ. Sci. Technol. v.38, p.4049-4055, 2004. 